\title{
POSITION OF LIGHT AND WATER IN ARCHITECTURE AND PHILOSOPHY OF ART
}

\author{
Aysegul Yurtyapan Salimi \\ PhD Candidate in Architecture Faculty of Near East University \\ Amineddin Salimi \\ PhD Candidate in Architecture Faculty of Near East University \\ Nuran Kara Pilehvarian \\ Dean \& Prof. in Architecture Faculty of Yildiz Teknik University
}

\begin{abstract}
Light and water re key elements and indicators are in human life. Water as a lifeblood is important in views, philosophies and cultures in the world and its role is considered beyond its functional role as a symbol of purity, birth and beauty. In ancient Persia, water was a sign of lighting and purity and was so valuable. Architects have always tried to make the best possible use of the environmental resources and water that was an important element to use all the beauty and perfection of water, so water becomes a factor in order to calmness, cleansing and peace. Light reflects the effects and nature of God whose presence is manifested in architecture. Light has always been a symbol of meaning and the world kingdom. Hence, light, occupies a central place in religious architecture. Light and water were placed in contemporary architecture and philosophy and in terms of beauty, have offered outstanding works in philosophy and architecture. So in this study, we have tried to pay to the importance and application of light and water in architecture and the arts and philosophy.
\end{abstract}

Keywords: Water, Light, Architecture, Philosophy, Art

\section{MIMARIDE IŞIK VE SU KONUMU VE SANAT FELSEFESİ}

$\ddot{O Z Z}$

temel unsurları ve göstergelerin yeniden 1şık ve su insan hayatı vardır. Bir can damarı olarak su dünyada görüşleri, felsefeleri ve kültürlerde önemli olduğunu ve rolünü saflığı, doğum ve güzellik sembolü olarak fonksiyonel rolünün ötesine kabul edilir. Eski İran'da, su aydınlatma ve saflık bir işareti oldu ve çok değerli oldu. Mimarlar her zaman tüm güzelliği ve suyun mükemmellik kullanmak için önemli bir unsur olan çevresel kaynakların ve su en iyi şekilde faydalanmak için çalıştık, bu yüzden su dinginlik, temizlik ve barış için bir faktör haline gelir. Işık varlığı mimarisinde tecelli Tanrı'nın etkilerini ve doğasını yansıtır. Işık her zaman anlam sembolü ve dünya krallığı olmuştur. Bu nedenle, 1şık, dini mimari merkezi bir yer işgal eder. Işık ve su felsefe ve mimarlıkta seçkin eserlerini teklif var, çağdaş mimari ve felsefede ve güzellik açısından yerleştirildi. Yani bu çalışmada, önemi ve uygulama 1şık ve su mimaride ve sanat ve felsefe ödemek için çalıştık.

Anahtar Kelimeler: Su, Işık, Mimarlık, Felsefe, Sanat

\section{INTRODUCTION}

Water plays an important role in the formation of human life. But when we go ahead and come to architecture, water finds a special place from the artistic point of view. Water is clear, fluid, calm and quiet. Architecture utilizes all water features and so the relationship between man and water shown in the 
architecture. Water, in scholar's philosophy, has the material and spiritual aspects. Also they always have admired water in religious mirror and cited it as a sacred element, because water is a vital element [10]. because the purity, dynamism, limpidity and light of water, is the principle of life, it has always been shining in Persian culture and religion and has been important. Water is very important in different philosophies too, and over time it has fresh flavor and passing time has given it a new shape. Many philosophers have considered everything related to the water and so, have formed broader concepts of symbolism. Light is a manifestation of God and its presence is manifested in architecture. Light plays an important role in reducing rigidity and coldness of stone and building. Light gives dynamic quality to architectural ornaments. Light leads patterns, shapes and designs into the moment. Architecture thinks of embodiment of the designs and materials to reflect light shine as main manifestation. In addition to the functional use of light, it always has symbolic value too. In architectural art, light is one of the components that have arisen alongside other concepts and elements, including design and order [5].

\section{THE HYPOTHESIS}

Light and water effects on architecture, philosophy and various arts.

\section{METHOD}

This study is done by using online study method, libraries and papers to consider the position of light and water in architecture.

\section{THEORETICAL FOUNDATIONS}

\section{LIGHT AND HUMAN}

From prehistoric times, always luminous objects that awakened the embodiment of a living object in mind were praised and respected by human being and they were enthusiastically greeted, served and worshiped them. This excessive attention to the element of light in the most basic human cultures and societies with different customs and religious beliefs also is viewed over time. Some communities applied sunlight in their ritual and others considered shining of luminous objects as a cause for interactions to achieve enigmatic areas that were beyond the terrestrial world. Even today in many Eastern schools that teach yoga use luminous objects for mental focus such as lamps, sun, moon, crystal light and fire use. In most religions, light symbolizes the divine wisdom is the source of all purity and goodness and spinning human out of the darkness of ignorance and shining the light of knowledge in him is always the ultimate goal [14]. Shining divine light into the body of material, namely the human soul, causes human growth and spiritual evolution. Consequently, to display this analogy in architecture of many religious buildings, light as a typical element and independent of other elements and concepts that were used in the building, was applied, in such a way that its beam is clearly visible within the dark and material body the of the volume. Deep and dark spaces of medieval churches and Islamic mosques that have been decorated with light elements are well able to convey a spiritual sense. In such spaces that are lit with poor lighting, by viewing vague shadows of objects and volumes, man tries to complete the pictures in his mind and with this action, He goes into a trance and the result is a sense of closing to the source of existence that awakens within him [14].

\section{LIGHT AND NATURE}

Natural light that carries the inner life energy is considered as a source of life on earth. In addition, the light can change face of a location by its different colors and effects, because in each season of the year, in different climates or at any time of day, light has its own face [8].

Also, any place has a special light that only belongs to that place. For example, in a desert of a tropical region, radiation is so intense and shadows are so short that to the viewer, Objects look vibrant and melting. Similarly, light in mountain, forest or coastal locations has its own characteristics and is distinct from other regions. When we direct the light to the built space, in fact, we have created a relationship 
between building and environment out of it. So different effects of an internal space, each with its own characteristics in terms of spatial perception, can be created [8].

\section{LIGHT IN ARCHITECTURE}

The beauty comes from light and brightness, otherwise, in the darkness, beauty is meaningless. Beauty is a truth that is perceived in the light of understanding, and we see the appearance beauty by our dearest sense that is sight. Light, whether spiritual or superficial, makes us to see the beauty, color and other features of objects. So this issue and dealing with it can have a special place in discussions of aesthetics and art. One of the sciences and arts that we can point to the role of light in it is architecture that has a detailed discussion on the use of natural light. Lighting devices are considered as the factors that are the source of artificial light.

In the Art of Architecture, light is one of the elements that beside other components and concepts such as structure, space order, materials, colors, etc, is provided and as a separate element must play its role in the design. One of the most important features of natural light is its sequence and transformation during the day that creates moving and shifting stances at different times.

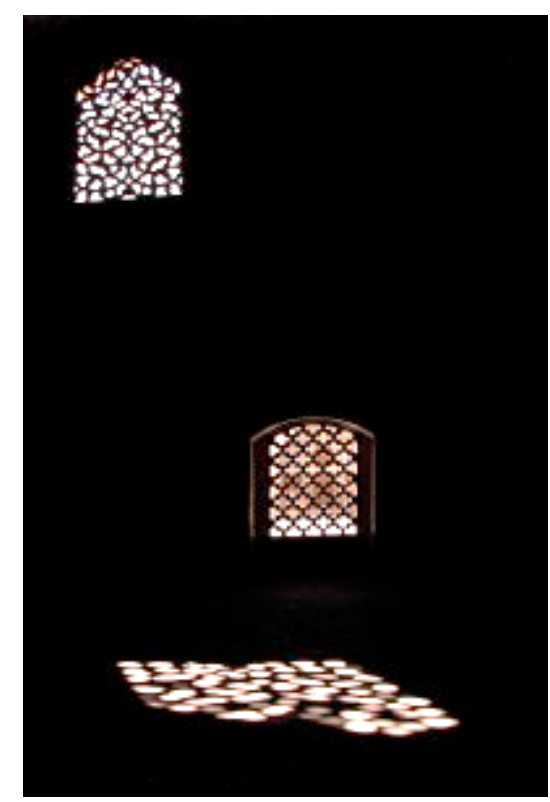

Figure 1. Light in interior

In the history of painting, the Impressionist period has paid attention to the light, when artists left their studios, and were busy painting in the sun with natural light.

The characteristics of this style, attention to color and light at different times of the day and reflect the colors of various objects in each other and the influence of surrounding colors and apply special color was pure. The characteristics of this style is paying attention to the color and the light at different times of the day, reflecting the colors of various objects in each other, influence of surrounding colors and the use of special and pure colors. This paper examines the role of light in architecture and interior design as a component and concept and in conclusion, we hope that in the future, like our ancestors; see the use of natural light in buildings as a fully effective element [12]. The importance of light is in creating harmony between colors, shades and penumbras, and in painting, using light for creating natural, happy, sad or scary space can be verified [19].

\section{LIGHTING IN INTERIOR ARCHITECTURE}


One of the important elements in the architecture is lighting. Lighting in a room not only provides comfort but also affects on the size of internal space. When the light of room is dimmer, it appears smaller and the more the room is brighter, it appears bigger. Lighting in the living room and family room is of great importance as it is a gathering place for the most hours of the day. Since the main source of light and home lighting is window, so for the use of natural light, installing net and silk curtains is more suitable. The best way to brighten up homes at night is using chandeliers and lights which are proportional to the height of the ceiling and wall color. Note that the lighting in the living room should induce safety and energy to households. For this purpose, it is better to use wall and ceiling lights with soft light that by reflecting light from the ceiling, give special warmth to the room. Rather, for reception room that should be very bright and light, use patterned and the slightly larger chandeliers that in addition to light, give a certain beauty to the room. As kitchen is the workplace of homemaker it should be bright and light. Using Halogen lights and Chandeliers with single LED will have a good impact on this goal. For sleeping room, it is better to use poorly lit bulbs and lampshades. If your bedroom is your workplace too, use colored bulbs that create wellbeing and calmness. Also in choosing chandelier, note to its coordination with other home elements [16].

Light is an element by which, viewing objects is possible. Light can forgive creative rhythm to the interior. Without light, form, color and texture cannot be felt. Lighting has important implications in interior. Proper lighting can make a space, pleasant and eye-catching. Beside aesthetic dimensions, lighting has practical dimensions too. Suitable illumination during the night in an interior can resolve sense of limitedness, ambiguity and fear. Proper lighting in a room can even make human face, warm and friendly. With the help of lighting, an interior can be turned into a variety of light islands. To create a basic classification and increased ease of access, we have prepared two separate lists for household lighting and public lighting. The aim of the lighting is reconstruction of external spaces in internal spaces and by doing so in addition to lighting; the sense is given to the environment too. Light source is the part that light emits from it, and light beam is light radiation to different parts [16].

By changing the lighting, dead building gets alive. Rooms facing the North, South, East and West, even in similar geometric circumstances and depending on the time of day and season of the year seem different. Natural light inherently has the feature of motion and difference in moments. It has been said about the light: "form can be revealed in the nature of things and plan, at the right moment, by using light tries to apply cosmic laws of nature to bring the form to the existence". Light needs to the substance and structure to perform a task. As Louis Kahn says: "The sun never knew how much big it is until it hit on the building and your choice of structural element should be like choice of characteristics of your desired light. So from the very beginning of the design, structure and material is considered according to the light [21].

\section{The use of natural light in architecture and energy production}

Light is the source of all existence. Light illuminates the surface of objects and denotes them and a visible surrounding and environment. And gathering shadows behind them gives depth to objects. Only within the borders of light and dark, objects have meaning, earn their shape and show it, their internal relations will be discovered and are endlessly interconnected like the endless loops of a chain. Light gives autonomy to objects and at the same time, limits their affiliation. We can even say that Light gives so much promotion to every object in its surroundings that the object is fully specified and vary with other objects [11].

For early humans, light was as a means for calculating the time. High-energy radiation of light that is reflected from the distant Sun to the Earth, gives the basic shape to the feeling and understanding of Primary human about the place. 
This light that was drawn by openings into the spaces that was made by him, gave this possibility to the people who lived through it to understand their being in touch with the surroundings. Today, technological progress and technology, has facilitated artificial lighting. But by artificial lighting, people stay away from their contact with nature and loss this relationship. Natural light can be directed to the architecture interior so that it can deepen space and define it and create a very exciting and stimulating space. Light cannot have a pleasant appearance alone. Darkness should be inside the light, so light can create its existence. This is darkness that reveals the brilliance and power of light [11]. People rely on natural light to reduce electricity consumption. This represents complexity of the use of natural light in architecture [20].

\section{HISTORY OF USING NATURAL LIGHT IN IRANIAN ARCHITECTURE}

Knowing about the process of using the sunlight is necessary as much as knowing about the process of the formation of materials or different shapes of building infrastructure for design. The earliest date we know about it, is third century of the fourth millennium BC, and in that time, architectures created light and shadow by forming level difference in exterior walls. The earliest documents and samples of doors and windows in Persian architecture may be founded in the design of material castles in the works of Sharokin. According to the ... design of Ashoori, we can recognize the windows that were built on the towers. In the Achaemenid period, In Persepolis, door status is clear and their heel often has remained. Also in these palaces, at the top of the doors and even the roofs, there has been made windows and skylights

Otherwise, how a few doors that often were closed illumined those large indoor spaces [14]. In principle one of the properties of Persian style is embedment reasonable and necessary shades and parasols for buildings. In this period, level difference principle was used to absorb light into. According to the researches of Professor Wolfgang, It turns out that the angle deviation of the buildings in Persepolis is placed in a way to create various shades and show the first day of the year and different seasons and this deviation lets Iranian architect to build needed places for living in a way that every house has the necessary amount of sunshine and light in different seasons [14]. Sassanid tended to show the contrast between shadow and brightness and this is apparent in all their buildings. Top of the dome of four arched buildings is like a skylight because they needed it to fire. Although in buildings that had the barrel vault, light usually was supplied from the parts which had flat roofs. The way of using the rocking Vault that turns back to Sassanid era allowed the architect to embed a window in the distance between the two rails and provide lighting for building. In Sassanid period that using dome was accepted and was one of the features of this architecture, we see that in the dome, there were fitted openings with holes and probably were covered by glass. As long as the Sassanid used supporting walls for bearing dome load, they only used the orifices embedded in the middle of the dome or the on it as skylight. But when they transferred the load of the domed roof on pier by arches, they could create skylights like a crescent in some parts of the hull of the dome [14]. The use of natural light and ventilation in modern architecture is possible with large ceiling windows [20]. Using daylight and midday light in Architecture is an informative experience for the use of architects in future generations, so that they can make use of experimental architecture and creating form and a sense of place of light in the design of religious buildings [20].

\section{THE STATUS OF LIGHT IN THE PHILOSOPHY OF ART}

Pure light that Suhrawardi has called it "Noorol anvar" (light of lights) is a divine truth and its lucidity is infinite, because of the intensity of light and grace. Superior light is the source of all beings, because the world in its all levels of reality is nothing but varying degrees of light and darkness. Suhrawardi says in this regard: "essence of the first absolute light that is God, illuminates continuously and is manifested in this way and creates all things and gives life to them with its rays and everything in this world is from his essence light, and beauty and perfection is a gift from His mercy, and redemption is achieving to this light". Sheikh Ashragh in describing the concept of light first provides evidence of his own criteria then considers if the lighting concept meets this criterion. He writes: If in universe there is something that

Submit Date: 10.02.2016, Acceptance Date: 25.03.2016, DOI NO: 10.7456/1060ASE/006 
does not need to be defined and described, it must appear to be apparent and obvious, and in universe, there is nothing more obvious and apparent than light, so it doesn't need to be defined [6]. In another text, for explaining further about the issue, Sheikh says: Whenever you want to find a rule for light absolute, that rule is this: light in the truth of its essence is the appearance and maker of appearance of other beings, and is more apparent than everything, and this apparentness is in excess of truth. In explaining Suhrawardi's idea, it can be said that:

Light is nothing but appearance; as appearance is just the truth of light [6]. The light of truth is not the limited, because the true extend is a combination of material and term, and everything that has not term and material cannot have a true extent. Another reason for the lack of any definition for light is that, if something is more apparent than everything, so it will not have any appearance maker and introducer, because one of the major conditions of introducer is that it should be more evident and apparent than the introduced object, and we know that nothing is more apparent than light [2]. So to understand the exact meaning of Light we must understand the element of "appearance" and our mind should not by wrong refers to visible light to apply this concept. Appearance is an evident concept that includes visible light too. For example, the emergence and revealing concepts and scientific forms for man, falls under the concept of emergence. Suhrawardi also says about the sensory or phenomenal light: "The emergence of phenomenal lights also, is not superfluous to them to necessarily be stealth per se, but also their appearance is from the fact of their nature. It's not that first, light becomes evident and then appearance and brightness are added and accompanied to it, and it is not true that light is not sufficient and it needs something else to make it appear. Because it would be impossible and every phenomenal light has appearance too and its emergence is its brightness, and it is delusion that our sight makes sun bright but shining of sun comes from its brightness, and even if all the people and sense owners destroy, brightness of sun will not be destroyed and disappear [4].

Light will be investigated in physics for its sensory attributes such as speed of light, refraction, reflection ..., but definition of light is not limited to these tangible aspects and definitions, and it has other non sensory features and aspects that intellect can grasp some of them like attributes such as the cause or the effect, being obligatory and the feasibility of the kinds and etc. One of the attributes that intellect reaches it and figures it out in its analysis of visible light, is attribute of emergence that is intellectual descriptive [2]. This description belongs to visible light that is achieved by rational and philosophical contemplation not experimental look. In other words, this attribute has been revealed by philosophy glasses not experience glasses. Thus it can be concluded that visible light can be discussed under the category of appearance or light; but for such special considerations we should be taken out of the field of science and be entered to the field of philosophy [2].

\section{THE ROLE OF WATER IN THE OLD MYTHS}

Water, as one of the main effects of life has long been interested in different cultures, as in many civilizations, we could find legends about emergence and development or relationship between water with the birth of the universe. A summary of the myths in different cultures is mentioned below:

Sumerians believed that at the beginning of life, there was nothing but water and all things are obtained from water: In the beginning of the life, there was only Nammo goddess that meant the first waters. This Goddess bearded a son and daughter. The name of her son was god of sky and the name of her daughter was goddess of Earth. In the Babylonian myth, goddess of the Ta'ame was introduced instead of Nammo goddess as water goddess [3].

Also Egyptian myth pointed to Ra' goddess that was the first goddess that came out of the first waters and after leaving, other goddesses were created. In Greek myth, ocean is introduced as goddess of first waters and she is the first goddess that has created the universe [3]. 


\section{WATER AND PSYCHOLOGY}

Human is a combination of spirit, mind and body. Just as the human body needs food, his mind and soul need elements to give him peace. In urban society that tall buildings and streets and machine lives have surrounded everywhere, effects of beauty and art, is the best refuge for tired and peace-loving soul of man. Nowadays, in cities we see elements with hard tissue such as concrete and ... instead of natural elements (vegetation).

Therefore, we should provide hermitage and beauty by using elements that have soft tissue to give peace to the human psyche. This location can be parks and urban gardens. One of these elements is water that whether at rest or in motion, strokes human spirit. Water movement and music has a considerable role in more manifestation of green space.

Water can be designed in the form of streams and springs for the quiet and serene places and in the form of waterfall and large jets for crowded and busy places [7].

\section{ESTABLISHING THE CENTRALITY BY USING WATER}

- Presence of water is due to the emergence of many population centers that is often located in the center core. The centrality not only is inserted in to architecture and urbanism, but also it is seen in other concepts such as religion, literary and art.

○ Forming, formable

- Inviting, bonding, separator

- Transient, current

- Landscape and visual

- Water sews environment together or separates them and in any case, has its role of inviting

- Water show in top, has different modes like the color of dishes and the way they are offered, so it creates a special landscape to reflect the environment that unity and diversity is manifested in it [9].

\section{WATER IN THE GARDEN OF PERSIA}

Water is one of the most important elements in the formation of the Persian garden and perhaps, with no exaggeration, it is the most critical and important element. Use of water in Persian gardening is very subtle and artistic, because in the Iranian garden, water is used not only for irrigation and supplying garden plants but also conceptual, poetic and artistic use of it has decorated garden space and with its presence, has created freshness, vitality, movement and beauty in the garden.

The way of emergence and presence of water in the garden is on the basis of specific concepts and its distribution is adherence to discipline and rules that on the one hand, pays attention to the physical and technical characteristics of irrigation and on the other hand, considers the concept of aesthetics, landscaping and architecture. In Persian garden, garden architecture is water architecture and mixture of water and building engenders a unique epic of poetry, magnificence and music in the privacy of trees.

Persian gardening warms water since the presence of it, as even the magnificent building as a symbol of home, calls entry of water into the garden and welcomes it as it should be, so water streams in the routes in a measured and intelligent way and presents in ponds and fountains and shouts in waterfalls and jets and manifests with its movement and sound and view and freshness. Form and manner of the presence and movement of water in the garden has its own system and is in harmony with the geometry and architectural structure and takes various forms in different kinds of Persian garden [13]. 


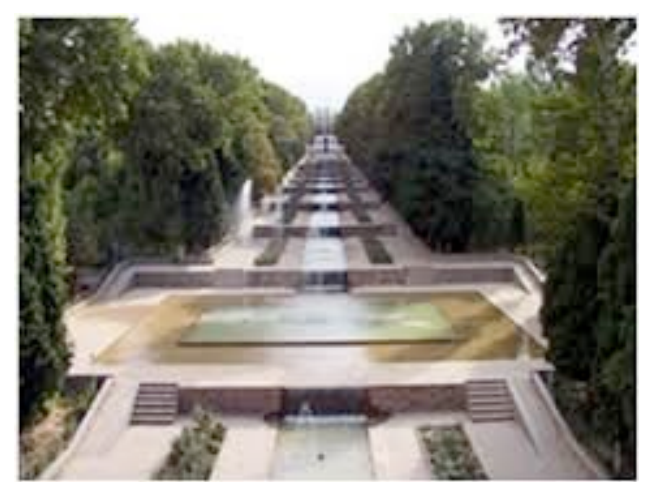

Figure 2. The water in Persian Garden

\section{WATER IN ARCHITECTURE}

The most effective, tangible and understandable feature of water in the architecture is its sign of formalism. Manifestation of water in architecture in different ways is the projection of opinions and ideas of designers. The special form of this discussion deals with the objective effects of water in architecture and gardening which includes "centrality, forming, inviting, bonding, separator, passing, running, dramatic and with landscape "features in environment and insists on this assumption that water in architecture is the main center element, and is considered in the context and is not marginal.

Enormous influence of water in Iranian architecture is in a way that even some of the main buildings and cities have been formed on its side. Existence of a source of water or fountain was a good reason to building homes and settlement.

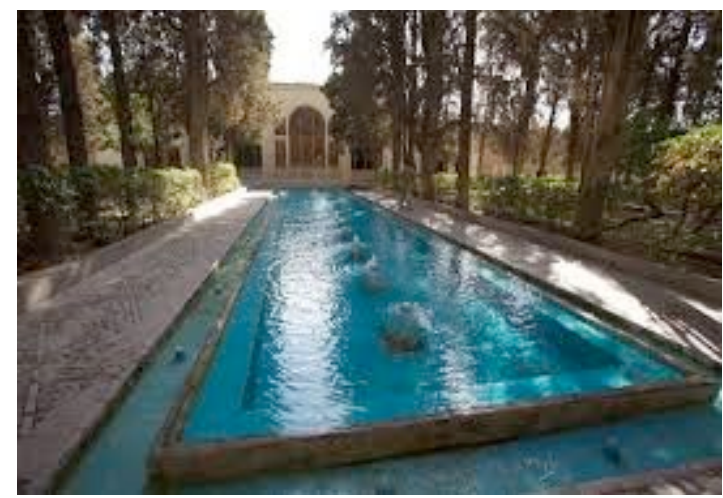

Figure 3. Water in Architecture

Water manifestation in architecture is seen as the key element, and architecture is placed around it; it gives shape and form to places, bonds and links the different spaces, passes through the environment in transient and current way or manifests with landscape and dramatically. These options may be manifested individually or together in an environment; however, they represent symbolic characteristics of the water [17].

\section{THE PLACE OF WATER IN PHILOSOPHY AND ART}

Undoubtedly, from the beginning of creation, the human beings were seeking to understand themselves and their surroundings and dominate it; so at first man used its imagination and was so interested to envision about the existence and the formation of universe. He was speaking about nature and its phenomena in order to understand existence and was searching the mystery of creation in the four elements of water, earth, fire and wind. After the birth of civilization and the establishment of the states and governments, Imagination and thinking about life spread in different cultures. 
Greeks that are likely to be the Iranians, were the first people in the West that spoke about the existence and the birth of the universe. For example, Homer, the famous poet in Greek that likely lived in the second half of the tenth century or the beginning of the ninth century $\mathrm{BC}$, believed that formation of the universe is followed by the advent of the oceans, and its distinct mark is ground water, such as sea and rivers.

Homer in Iliad writes about it: The Okehanos (ocean) [15]. So we can understand that he knew the existence of the universe and all effects of existence and nature, thanks to the presence of water, and believed that everything was taken from it.

After Homer, another Greek poet called Hesiod that lived in the second half of the eighth century BC. saw the creation of the world in an empty and open space where the sky and the earth have not been separated from each other and everything flows in integration of infinite space. He has well described this attitude in his poems. In Greek myth, Dionysus was the son of Zeus, the god of gods and god of the earth, and the God of vineyards, orchards, lushness and fertility, and this was so important, because this was only possible by water. For this reason, the source of worshipping water can then be searched in the religious mirror of farmers [15]. In any case, before arising philosophical thought in the West, in the East, the dimensions of the human imagination considered water as the first principle and as cleaning against pollution, especially in the rituals of that period. Thales that is perhaps the first philosopher of ancient history gave his opinion about the creation of the world. He believed that the first principle of all things is water and the earth is floating on water [15].

We do not know exactly what his purpose was. Maybe he believed that everything emerged from the water and is transformed to the water again.

Because he lived in a city named "Maliteh" that was like an island and water was very important for its people, like the time that Thales lived in Egypt; certainly he paid attention to the fertility of the fields after flooding and suppressing water of Nile river. He saw that how after every rainfall, worms have been found. A group believes that his thinking was influenced by Babylonians thinking, because they believe that "Absoo" is representative of sweet waters and "Tyamt' is representative of salty waters. He was impressed by this thought and considered water as the origin of world phenomena. The reason of tendency toward this thought can be that, as water has no definite shape and can accept any shape, so this leads him to think about water. The matter that water is the source of life and has motion draws his mind into the water and all appearances of existence also have this feature [19].

\section{CONCLUSION}

Water and light in Islamic philosophy, is the base of the universe and the brightness of the environment and at the same time is the factor of cleansing, purity and brilliance. These traits are associated with the fact of building in architecture in such a way that their presence in the context of Islamic architecture makes the building pure and bright. The presence of water and light in architecture, especially in mosque, is a physical factor for beauty, purity, brilliance. Since light used in ancient architecture, is a combination of colors, so it should be said that this is the effect of color that gives meaning to life and is an affective element for environment. Architect tries to make an interaction between man and nature in architecture by understanding the dynamic and changing nature of environment and with awareness of the importance of light. Thus, by using special materials and appropriate use of it and creating shades and volume combinations and surfaces with different textures, he shows different effects in his architecture. The reason of the special sanctity of water in the East, especially among Iranians and Muslims, was that water has always been the key element in locating and shaping to spaces. Light and water are the elements that traditionally have played an important role in traditional Iranian architecture. The use of water and light together is a work that gives mystical sense to space, especially the religious spaces such as mosques. By

Submit Date: 10.02.2016, Acceptance Date: 25.03.2016, DOI NO: 10.7456/1060ASE/006 
considering light as a core component of the space and considering water as something that gives life to environment, these two overall combinations create a specific philosophical shape. Hence the presence of light and water, which manifest in various forms in environment, is visualization and manifestation of beliefs and attitudes of space creators towards them which is originated from its high value on human life.

\section{REFERENCES}

Amoozegar, J., 2001, Mythical History of Iran, fourth edition, SAMT publishing, Tehran

Omid, Masoud, 2007, ontology of Sheikh Eshragh, Bashgah-e-Andisheh Publishig

Behbahani, Akhavan Abdulhadi, 2003, an article about role-playing of water in Sumerian and Babylonian myths ", Mah-e-honar book, Issue 57

Boorian, Muhammad Ali, 2010, Elements of the Philosophy of Eshragh from the viewpoint of Suhrawardi, translated by Mohammad Ali Sheikh, Shahaid Beheshti University publication

Poordeimi, J., 2008, the impact of daylight to perception of human, Saffe publication.

Tadayon, Ataullah, Suhrawardi 1988, Sheikh Eshragh Madih saraye noor, Tehran Publishing

Jvaheri, Parham and Mohsen, 2001, Solution of water in Fars history, the Iranian National Committee on Irrigation and Drainage, Water National Treasure of Iran, Tehran

Dibaj, M., 2005, Space of light and architecture of lighting, baghe nazar juornal, the second year.

Danesh doost, yaghoob, 2007, Article of Iranian garden, Asar Journal, Cultural Heritage Organization of Iran, Tehran

Razi, H., 1992, Ayine mehr, Mithraism, first edition, Bejjat., Tehran.

Sadat Akhshik, S 0., 2011, Consideration of status and effect of color and light Symphony in Postmodern architecture of libraries, Shamse magazine, Volume 10, Number 311

Soltanzadeh, h., 2009, lighting and architectural lighting, architecture and culture journal, $10^{\text {th }}$ year, Issue thirty-fifth

Shakeri, M., 2003, Iranian garden and water essay, Mahe honar book, No. 58-57, Tehran

Ghodoosi far, H., 2009, a look at the place of light in art, light sculpture, architecture and culture journal, of the tenth year

Kashefi, Jalal al-Din., 2012, Holy status of water in reliefs and statues of Taq-e Bostan

Abbasi, Z. 2009 movement and light in architecture, architecture and culture magazine, $10^{\text {th }}$ year, Issue thirty-fifth

Alam-ol- Hoda, Hoda, 2003, article "Water in Iranian architecture" Book of Mahe honar, No. 58-57, Tehran

Barzl, Amnon, 2008, Introduction to the Art of Light, race, Art Journal Pyytra, Rojin, 2006, Women Philosophers in ancient Greece and Rome

Salimi, Amineddin, 2015, Investigating on the Interior Space Quality Affecting by Light and Color Shultz, Christian, 2002, architecture: the meaning and place, 0 . 